g-nienatatual

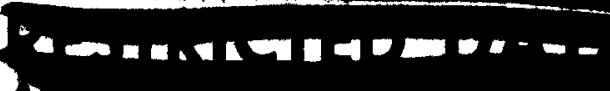

Ah

Subcontract NP-1

Westinghouse Astronuclear Laboratory
SNPO-C Pecosdes
WANL-TME - 1869

October 22,1968

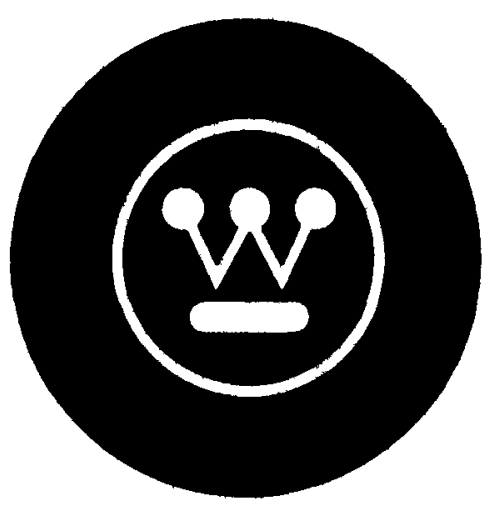

\title{
PEWEE I FABRICATION REPORT
}

(Title Unclassified) 


\section{DISCLAIMER}

This report was prepared as an account of work sponsored by an agency of the United States Government. Neither the United States Government nor any agency Thereof, nor any of their employees, makes any warranty, express or implied, or assumes any legal liability or responsibility for the accuracy, completeness, or usefulness of any information, apparatus, product, or process disclosed, or represents that its use would not infringe privately owned rights. Reference herein to any specific commercial product, process, or service by trade name, trademark, manufacturer, or otherwise does not necessarily constitute or imply its endorsement, recommendation, or favoring by the United States Government or any agency thereof. The views and opinions of authors expressed herein do not necessarily state or reflect those of the United States Government or any agency thereof. 


\section{DISCLAIMER}

Portions of this document may be illegible in electronic image products. Images are produced from the best available original document. 


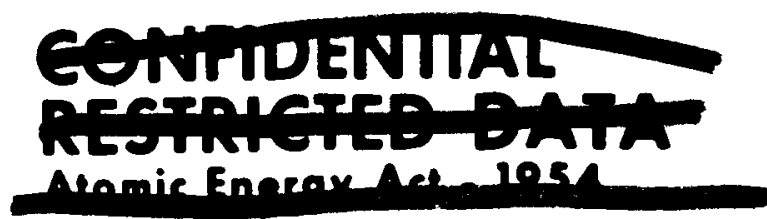

\section{MASTER}

Subcontract NP-1

\section{NOTICE}

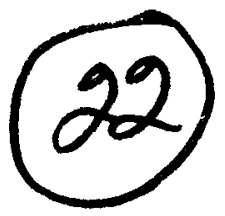

Westing.

This report was prepared as an account of work This rest United States Government. Neither United States nor the United States Energy the United States nor the Administration, nor any of Research and Development Administren contractors, their employees, nor any of their makes any subcontractors, or their employes, mes any legal warranty, express or implied, or assum completeness liability or responsibility for the accuracy, completeness or usefulness of any information, apparatus, product or usefulisced, or represents that its use would no infringe privately owned rights.
WANL-TME - 1869

October 22,1968

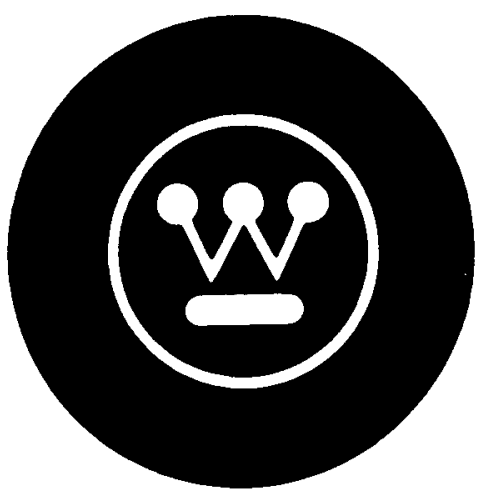

\section{PEWEE I FABRICATION REPORT}

DISTRHBUTHON DE IHIS DOCUMENT. IS UNLIVITED

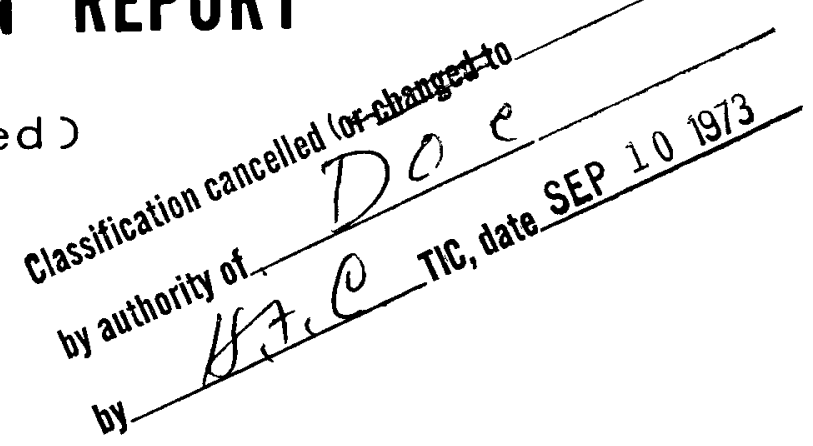

Prepared by:

\section{WNCO Staff}

Approved by:

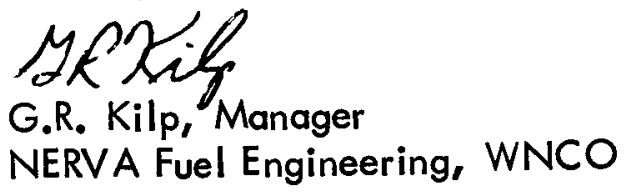

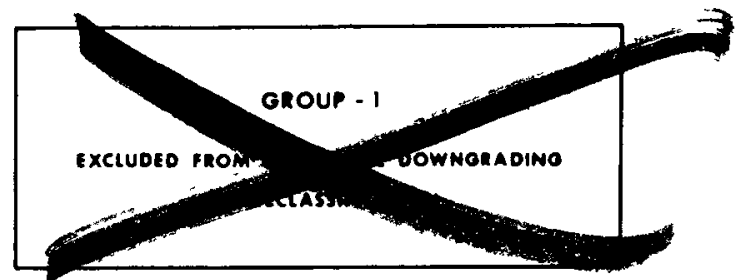

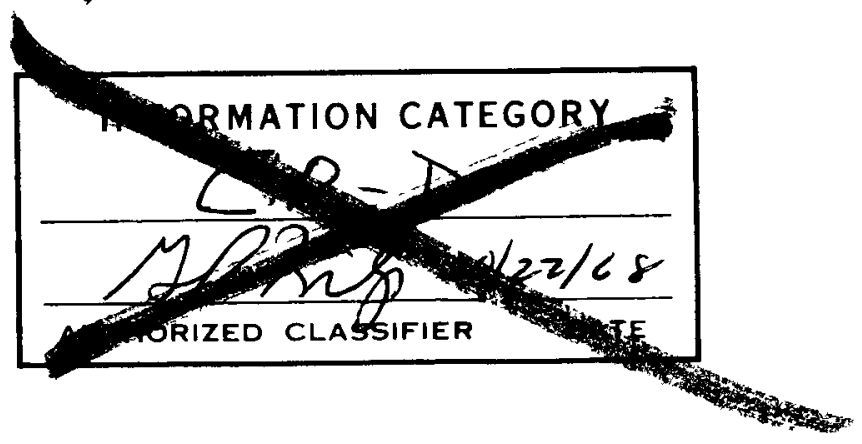

\begin{tabular}{|c|c|c|}
\hline SPECIAE HTTEVIEIV & $\begin{array}{l}\text { Riviener } \\
\text { KAW }\end{array}$ & $\begin{array}{lll}\text { Class. } & \text { Date } \\
& 4 & -8\end{array}$ \\
\hline Class: _ & & \\
\hline
\end{tabular}




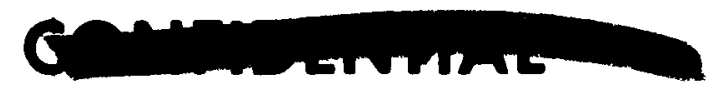

(6) Astronuclear

\begin{abstract}
(U) This report presents the fabrication history of the uranium-loaded graphite fuel elements for the PEWEE I reactor by Westinghouse Astronuclear Core Operations (WNCO) at Cheswick, Pennsylvania, during the period from December 1967 through April 1968.

(U) It is the purpose of the report to summarize the production history of the fueled elements and reactor support hardware for the PEWEE I core, with particular emphasis being placed on the development and implementation of new or revised processing techniques and production schedule records.
\end{abstract}

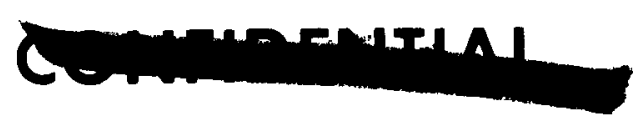




\section{TABLE OF CONTENTS}

Section

Page

1.0

INTRODUCTION (U)

2.0

PROGRAM REQUIREMENTS (U)

2. 1 Fuel Element Schedules (U)

2.2 Fuel Elements (U)

3.0

FABRICATION HISTORY OF FUELED ELEMENTS

(U)

3. 1 Materials and Extrusion Batch Formulation(U) 4

3.2 Extrusion (U) 4

3.3 Curing, Baking, and Graphitizing (U)

3. 4 Tip Brazing (CRD)

3.5 Machining (U)

3.6 Leaching $(U)$

3.7 Niobium Carbide Coating (U)

3. 8 Molybdenum Coating (CRD)

4.0 NbC COATING OF SUPPORT HARDWARE (U) 8

4. 1 Pedestal, Outer Cup, and Tapered Washer (U) 8

4.2 Inner Cups (U) 8

4.3 Outer Sleeve (U) 8 


\section{LIST OF TABLES}

$\underline{\text { Table }}$

Page

1

PEWEE I Raw Materials (U)

PEWEE I Process Procedures (U)

PW-1 Ordering Summary - Elements (U)

Bi-Weekly Summary of PW-1 Fuel Element Manufacturing Core Candidate Elements Only Plus LASL Samples (U)

Final PW-1 Yields Core Candidate Elements Only (U)

Engineering and Test Evaluation Elements (U)

Axial Support Hardware

PEWEE-I Element Permeability (U)

PEWEE-I Extrusion Run 


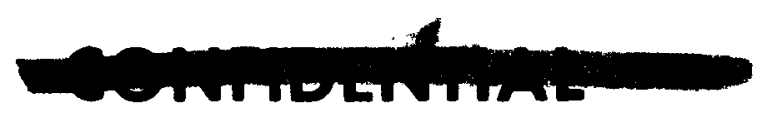

(W. Astronuclear

\subsection{INTRODUCTION (U)}

(U) Fuel element production for the PEWEE I core included a number of successful manufacturing modifications.

(CRD) These included (1) the use of a $75 \% \mathrm{NbC} / 25 \%$ composite tip, (2) a high hydrogen/ salt ratio chemistry for the standard high temperature NbC process (GED), (3) a new low temperature $\mathrm{NbC}$ coating using a methane gas stream additive as the source of carbon, and (4) fixture modifications to coat a new system of support hardware.

(U) These modifications are reflected in the raw materials and processing procedures used for PEWEE I manufacturing. Tables 1 and 2 are lists of raw materials and WNCO process specifications, respectively.

(U) The remainder of the report is a presentation of the WNCO production effort for the PEWEE I reactor. 


\subsection{PROGRAM REQUIREMENTS (U)}

\section{1 FUEL ELEMENT SCHEDULES (U)}

(CRD) The PEWEE I production began with fueled extrusions during the week ending December 7, 1967. Processing of elements through subsequent steps of manufacture included coordination of the combined efforts of WNCO, $Y-12$, and WEFF to accomplish the desired matrix and coating variables, including additive and impregnated elements coated by GEM and GED processes. Schedules of extrusion through final inspection, certification, and delivery were maintained throughout the period. GED coating at WNCO began on February 13, 1968 and was completed on March 14, 1968. GEM coating at WEFF began on February 27, 1968 and was completed on March 26, 1968. "X" coating of GED-coated elements began on March 8, 1968 at WNCO and was completed on March 29, 1968. Final inspection and final shipment of all fuel elements from WNCO were completed on schedule on April 15, 1968.

\subsection{FUEL ELEMENTS (U)}

(U) Ordering of fuel elements from WNCO for PEWEE I was accomplished by work orders prepared by WANL Production Control. Table 3 is a summary of this effort. This tabulation indicates the type of element, pertinent WANL drawing, processing suppliers, order number and quantities, number of applicable change notices against original order, and some description of the element matrix, coating, and physical geometry.

(CRD) The basic work order included a matrix exchange of elements with additive elements received from $\mathrm{Y}-12$ in the "as-graphitized" condition and impregnated elements shipped to $Y-12$ in the "as-leached, re-graphitized" condition. The supplier for finished elements was designated by "Manufacturer through Graphitize - Manufacturer after graphitize, " i.e., $W-W_{0} \quad Y-W_{0} *$

* W - Westinghouse Astronuclear Laboratory Y - Y-12 Plant, Oak Ridge National Laboratory 


\section{COMrisentrat \\ (2) Astronuclear \\ Laboratory}

(U) Table 4 summarizes the weekly progress from extrusion through shipment of core candidate elements and required samples. Table 5 summarizes overall process yields by process stage for core candidate elements. All elements produced at WNCO were delivered. In addition to core candidates, elements were shipped for required test samples, component tests, or other evaluations (see Table 6).

(CRD) WNCO delivered to LASL 157 core, spare, and sample fuel elements, which was 59 elements over the required quantity.

(U) WNCO delivered to WANL 63 sample and corrosion test elements for qualification of core candidates shipped to LASL

(U) WNCO delivered 40 core candidate elements to $Y-12$ in the as-impregnated condition and received 155 elements in the as-graphitized condition as a matrix exchange for further processing.

(U) WNCO delivered 220 elements to WANL for component testing and other evaluation. Table 6 lists the requisitioning section, type of evaluation, quantity desired, and quantity delivered.

(U) Table 7 lists the axial support hardware ordering information. This table lists type, style, pertinent WANL drawing, order number, number of applicable change notices against original order, quantities processed, quantities shipped for final evaluation at WANL, and yield ratios of quantities processed related to quantity shipped. 


\section{0 FABRICATION HISTORY OF FUELED ELEMENTS (U)}

\section{1 MATERIALS AND EXTRUSION BATCH FORMULATION (U)}

(CRD) PEWEE I fueled elements were fabricated with 85 parts of cross-blended graphite flour to 15 parts of carbon black, General Atomic fuel beads, and 27 percent "varcum" catalyzed with maleic anhydride.

(CRD) Aim fuel loadings of graphitized elements were calculated by the carbon/uranium balance procedures utilized previously. The relationship between aim loading and desired final loading for materials utilized was as follows:

Aim Loading $(\mathrm{mg} / \mathrm{cc})=$ Final Loading $(\mathrm{gms} / \mathrm{inch}) \times 192.93$

(CRD) The only uranium loading value produced at WNCO was $525 \mathrm{mg} / \mathrm{cc}$ (final).

(U) A tabulated summary of PEWEE I permeability data for elements extruded at $Y-12$ and machined at WNCO as well as those fabricated entirely at WNCO is presented in Table 8.

\subsection{EXTRUSION (U)}

(CRD) The extrusion run was normal and in accord with previous experience at a pressure of $95 \pm 10$ tons and a rate of $100+10 \mathrm{in.} / \mathrm{min}$. Variations in these parameters and an extrusion summary are given in Table 9.

(U) Twenty-four hour engineering coverage was provided during the extrusion of PEWEE I fuel elements.

\subsection{CURING, BAKING, AND GRAPHITIZING (U)}

(CRD) Cure, bake, and graphitization procedures for PEWEE I elements were identical to NRX $-A 6$ and XE-2 procedures.

\subsection{TIP BRAZING (CRD)}

(CRD) Fabrication of the PEWEE I elements utilized a "transition tip" consisting of an unfueled transition piece brazed to a $75 \% \mathrm{NbC} / 25 \% \mathrm{C}$ hot end wafer. The "transition tip" was provided to WNCO as a unit. WNCO then brazed this unit onto the hot end of the

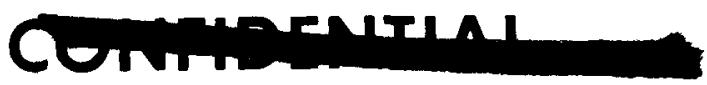


element. The brazing operation was the same as that for XE-2 production, using -325 mesh molybdenum powder.

(CRD) The tip-to-element joint was induction-heated to a surface temperature of $2425^{\circ} \mathrm{C}$, held for 10 seconds, and allowed to cool. A 1500 psi compressive load was maintained throughout the thermal cycle.

\section{$3.5 \quad$ MACHINING (U)}

(CRD) The PEWEE I elements were machined according to the same manufacturing procedures used for NRX-A6 and XE-2 fuel elements. A total of 470 carbide-tipped elements, plus 80 non-fuel elements, were milled to drawing requirements for across-flats dimensions without any serious degradation in the diamond cutting tools. This performance matched the best of any previous diamond milling for high loaded graphite-tipped elements.

(CRD) The reaming of carbide versus graphite-tipped elements was similar in regard to tool wear. However, twice as much tooling wear was noticed for reaming the $2-1 / 2$ percent additive elements.

\subsection{LEACHING (U)}

(CRD) The PEWEE I fuel elements were leached with the same process used for NRX-A6 and $X E-2$.

\subsection{NIOBIUM CARBIDE COATING (U)}

(CRD) A series of development runs was made in preparation for PEWEE I production, utilizing both the "NRX-A6" and "high hydrogen" chemistries. The "high hydrogen" process utilized a 2.25/1 hydrogen to salt ratio compared to the conventional $1 / 1$ ratio. This enabled the coating time for equivalent thicknesses to be reduced from 24 hours to 14 hours. An evaluation of the corrosion behavior of elements receiving both types of coating failed to isolate any marked differences between the two. Consequently, the high hydrogen process was selected for its greater productivity potential.

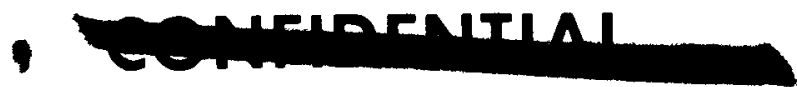




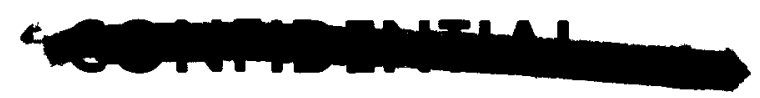

(CRD) Aim coating thicknesses for PEWEE I were 1.2 mils at the midband and 2.8 mils at the hot end. Temperatures required to achieve this profile were $1370^{\circ} \mathrm{C}, 1530^{\circ} \mathrm{C}$, and $1780^{\circ} \mathrm{C}$ for the cold end, middle, and hot end of the elements, respectively. Improved temperature control was obtained by establishing voltage tables for each zone on the furnace coil and applying predetermined logic to make adjustments. This prevented the technician from making arbitrary power adjustments and succeeded in decreasing the range of temperatures on a given sight port to $\pm 5^{\circ} \mathrm{C}$.

(CRD) Even with good temperature control, some problems with weight gain and thickness profile were encountered. The average coating run weight gain ranged from 63.0 grams to 78. 0 grams. The mid-band thickness ranged from 0.9 mils to 1.5 mils. The hot end thickness ranged from 2.4 mils to 3.0 mils. This control spread may be due to difficulties encountered with the generation of constant salt delivery rate from saturators. The newly installed salt loss control systems should improve this situation considerably.

(CRD) Both the "A6" chemistry and "high hydrogen" chemistry processes are identified as "GED" processes (G end diffusion). The WEFF facility, meanwhile, developed the GEM ( $G$ end methane) process for use in PEWEE I. This latter process is operative at low temperatures (approximately $1050^{\circ} \mathrm{C}$ ), and the carbon is supplied from the methane content in the gas stream rather than the element. Weight gain and profile problems were evident in these runs. (CRD) In addition, coarse crystals were deposited at the inlet end of the channels and the coated across-flats dimension at the hot end exceeded drawing limits. The across-flats dimensional control of GEM-coated elements is more difficult than for GED coatings because the coating buildup is 100 percent of the total coating thickness and because there is no selflimiting effect due to diffusion of carbon.

\subsection{MOLYBDENUM COATING (CRD)}

(CRD) The molybdenum overcoating process was modified (increased total gas flow 24 percent) to maintain the same coating gas velocity for the high-void PEWEE I elements as was utilized for the NRX-A6 and XE-2 low-void elements. 


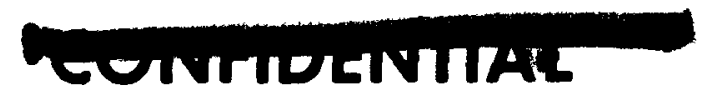

(W) Astronuclear

(CRD) Coating profiles, as determined with resistance measurements, were similar to previous core production profiles; weight gains were equivalent when the bore size differences were taken into account. Table 10 is the production summary including weight deposition and retention values. It should be noted that the standard matrices (G05K) retained less molybdenum than the additive elements (G07K), which in tum, retained less than the impregnated (G06K) elements. No gross abnormalities or problems were experienced throughout the production campaign. 
4. $0 \mathrm{NbC}$ COATING OF SUPPORT HARDWARE (U)

4. 1 PEDESTAL, OUTER CUP, AND TAPERED WASHER (U)

(CRD) The substrate for PEWEE I pedestals, outer cups, and tapered washers was a $75 \mathrm{v} / \mathrm{o}$ $\mathrm{NbC} / 25 \mathrm{v} / \mathrm{o}$ graphite composite. The components were coated with 0.5 to 2.0 mils of $\mathrm{NbC}$ deposited at $1900^{\circ} \mathrm{C}$ during a 4-hour period.

\subsection{INNER CUPS (U)}

(CRD) The pyrolytic cups were coated with 0.7 to 1.7 mils of $\mathrm{NbC}$ deposited at $1960^{\circ} \mathrm{C}$ during a 3-hour period。

\section{3 OUTER SLEEVE (U)}

(CRD) The graphite sleeves were coated with 2.0 to 3.5 mils of $\mathrm{NbC}$ deposited at $1940^{\circ} \mathrm{C}$ during a 6-hour period. This coating was performed in two steps to allow rotation of the component on the fixturing to eliminate coating defects. 
TABLE I (CRD)

PEWEE I RAW MATERIALS (U)

\begin{tabular}{|c|c|c|}
\hline Material & Specification & Supplier \\
\hline Special Uranium Particles & PDS $30050-C$ & General Atomics \\
\hline Graphite Flour & PDS 30046-B & Great Lakes Carbon Company \\
\hline Carbon Black & PDS 30047-B & R. T. Vanderbilt Company, Inc. \\
\hline Furfuryl Alcohol & PDS 30048-B & Varcum Chemical Company \\
\hline Maleic Anhydride & $\begin{array}{l}\text { PDS 51300-AB } \\
\text { (Rev. C) }\end{array}$ & Fisher Scientific Company \\
\hline \multirow[t]{3}{*}{ Niobium Pentachloride } & (1) PDS 30052-C & $\begin{array}{l}\text { Atomergic Chemetals (CIBA), } \\
\text { P. O. No. 59-NUB-80372 \& } \\
90177\end{array}$ \\
\hline & $\begin{array}{l}\text { (2) GFE (S.O.Y. } \\
84327)\end{array}$ & $\begin{array}{l}\text { Union Carbide Nuclear Corpora- } \\
\text { tion, Y-12 Plant }\end{array}$ \\
\hline & (3) $33 Y-7266 \mathrm{~V}$ & $\begin{array}{l}\text { Union Carbide Nuclear Corpora- } \\
\text { tion, Y-12 Plant }\end{array}$ \\
\hline $\begin{array}{l}\text { Anhydrous Hydrogen } \\
\text { Chloride }\end{array}$ & $\begin{array}{l}\text { PDS 52217-Ap } \\
\text { (Sub B) }\end{array}$ & $\begin{array}{l}\text { Frontier Chemical Company, } \\
\text { Air Products and Chemicals }\end{array}$ \\
\hline Hydrogen & PDS 3057-F & Air Products and Chemicals \\
\hline Argon & $\begin{array}{l}\text { PDS 52118-BA } \\
\text { (Sub A) }\end{array}$ & Air Reduction Sales \\
\hline Molybdenum Hexacarbonyl & PDS 30095 & Climax Molybdenum Company \\
\hline Transition Tip & $910 \mathrm{E} 185$ & WANL \\
\hline $\begin{array}{l}\text { Brazing Powder } \\
\text { (For Tips) }\end{array}$ & PDS 30179-1 & $\begin{array}{l}\text { Fansteel Metallurgical Corpora- } \\
\text { tion }\end{array}$ \\
\hline Niobium Carbide Powder & PDS 30104-D & Kawecki Chemical Company \\
\hline
\end{tabular}


TABLE 2 (CRD)

PEWEE I PROCESS PROCEDURES (U)

\begin{tabular}{|c|c|}
\hline AfF No. & Title \\
\hline 1. 1010 & Material Preparation and Dry Carbon Ingredient Blending \\
\hline 2. 1013 & $\begin{array}{l}\text { Procedure For Proof Testing Strength of Brazed Joint at Element/Tip } \\
\text { Interface }\end{array}$ \\
\hline 3. 1020 & Catalyzed Binder Preparation \\
\hline 4. 1025 & Batch Formulation \\
\hline 5. 1030 & Mixing Procedure \\
\hline 6. 1040 & Extrusion Procedure \\
\hline 7. 1050 & Cure Procedure \\
\hline 8. 1060 & Bake Procedure \\
\hline 9. 1065 & Procedure for Induction Brazing Tips to As-Graphitize Elements \\
\hline 10. 1066 & $\begin{array}{l}\text { Procedure for Cantilever Shear/Flexure Testing Ultimate Strength of } \\
\text { Tip Brazing Operator Qualification Samples }\end{array}$ \\
\hline 11. 1070 & $\begin{array}{l}\text { Graphitizing Process for Unfueled and Fueled Graphite Shapes } \\
\text { (35-Element "E" - Furnace) }\end{array}$ \\
\hline 12. 1080 & Procedure for Leaching of Fueled Graphite Shapes \\
\hline 13. 1091 & $\begin{array}{l}\text { Coating of Unfueled Graphite Support Blocks, Insulating Cups, and } \\
\text { Washers }\end{array}$ \\
\hline 14. 1095 & Sequential Bore/O.D. Coating of Fueled Graphite Shapes \\
\hline 15. 1110 & $\begin{array}{l}\text { Procedure for Packing and Shipment of Final Machined and Coated } \\
\text { Elements }\end{array}$ \\
\hline 16. 1140 & Final Bore Processing of Fueled Graphite Shapes \\
\hline 17. 1160 & Procedure for Loading Low Temperature Furnace Saturators \\
\hline 18. 1270 & $\begin{array}{l}\text { Graphitizing Process for Fueled and Unfueled Graphite Shapes } \\
\text { (74-Element "AE" - Furnace) }\end{array}$ \\
\hline
\end{tabular}


TABLE 3 (CRD)

PW-1 ORDERING SUMMARY - ELEMENTS (U)

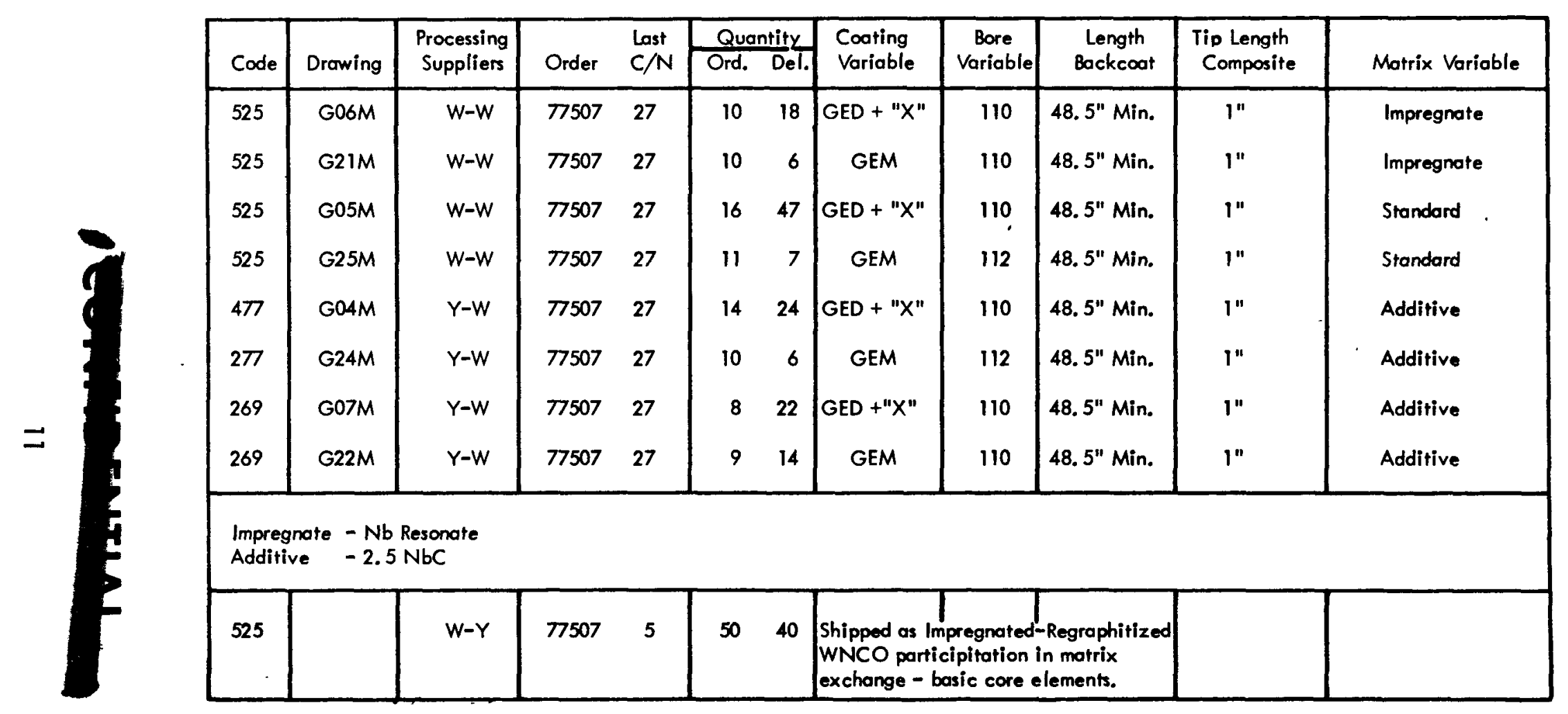




\section{TABLE 4 (CRD)}

BI-WEEKLY SUMMARY OF PW- I FUEL ELEMENT MANUFACTURING

CORE CANDIDATE ELEMENTS ONLY PLUS LASL SAMPLES

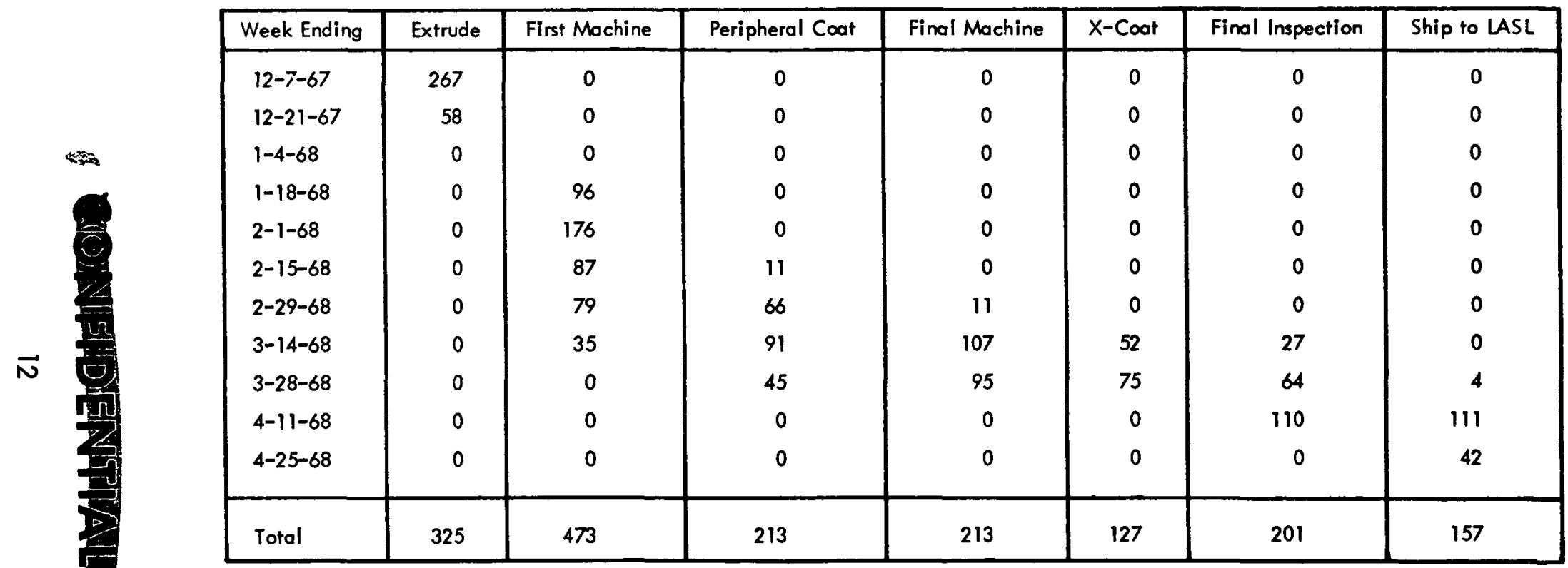

5

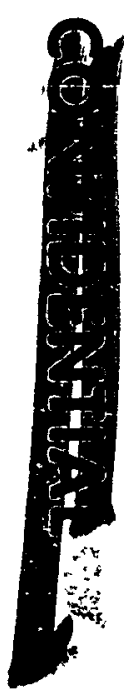




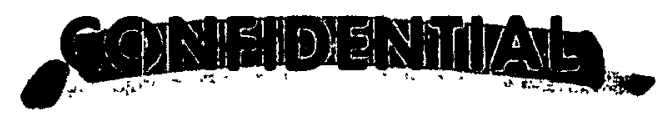

TABLE 5 (CRD)

FINAL PW- 1 YIELDS

CORE CANDIDATE ELEMENTS ONLY (U)

\begin{tabular}{|l|c|c|}
\hline Process Stage & $\begin{array}{c}\text { No. of Elements } \\
\text { Through Stage }\end{array}$ & $\begin{array}{c}\text { Yields to } \\
\text { Work Order }\end{array}$ \\
\hline Extrude and Cure & 325 & 3.34 \\
Bake & 325 & 3.34 \\
Graphitize & 325 & 3.34 \\
Tip & $478^{*}$ & 3.32 \\
First Machine & 473 & 3.28 \\
First Inspection & 473 & 3.28 \\
Leach & 452 & 3.14 \\
Leach Inspection & $452^{* *}$ & 3.14 \\
Furnace Processing & 213 & 1.48 \\
Final Machining & 213 & 1.48 \\
Nb Inspection & 213 & 1.48 \\
X-Coat & $127^{* * *}$ & 1.14 \\
Final Inspection & 201 & 1.40 \\
Ship to LASL (Core) & & 1.00 \\
Ship to LASL (Samples) & 144 & ---- \\
Ship to WANL (Spec Samples) & 13 & --- \\
Ship to WANHES (Corr. Test) & 12 & ---- \\
Ship to Y-12 (As-Leach) & 51 & ---- \\
\hline
\end{tabular}

* Includes 155 received from $Y-12$.

** Includes 40 shipped to $Y-12$.

*** Yield based on shipment quantity of 111 as-" $X "$-coated. 


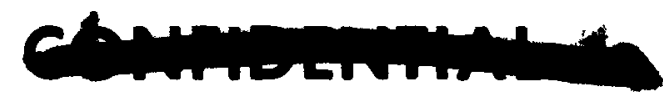

TABLE 6 (CRD)

ENGINEERING AND TEST EVALUATION ELEMENTS (U)

\begin{tabular}{|c|c|c|}
\hline Requisitioning Section & $\begin{array}{l}\text { Quantity } \\
\text { Required }\end{array}$ & $\begin{array}{l}\text { Quantity } \\
\text { Delivered }\end{array}$ \\
\hline Materials and Process Development & 32 & 32 \\
\hline Materials Testing Coating Stress Analysis & 31 & 31 \\
\hline EML Physical Property Testing & 66 & 66 \\
\hline Fuel Development Coating Evaluation & 14 & 14 \\
\hline TFL Corrosion Rig Development & 4 & 4 \\
\hline MTLS Extended Tip Development & 16 & 16 \\
\hline MTLS Physical Property Testing & 20 & 20 \\
\hline WNCO Coating Development & 8 & 8 \\
\hline WNCO Tip Braze Development & 3 & 3 \\
\hline Program Control Pool Coated & Bal. & 19 \\
\hline \multirow[t]{2}{*}{ Uncoated } & & 7 \\
\hline & & 220 \\
\hline
\end{tabular}


TABLE 7 (CRD)

AXIAL SUPPORT HARDWARE (U)

\begin{tabular}{|c|c|c|c|c|c|c|c|}
\hline Type & Style & WANL Drowing & Ordor & $\begin{array}{l}\text { Last } \\
\mathrm{C} / \mathrm{N}\end{array}$ & $\begin{array}{l}\text { Quantity } \\
\text { Processod }\end{array}$ & $\begin{array}{l}\text { Quantity } \\
\text { Shipped }\end{array}$ & $\begin{array}{l}\text { Processed/Shippod } \\
\text { Rate }\end{array}$ \\
\hline Pedestal & Regular & $929 F 015 \mathrm{GOIA}$ & 79241 & 5 & 63 & 56 & 1.13 \\
\hline Sleeve & Outer & $9810375 \mathrm{HO} 2$ & 79245 & 5 & 132 & 76 & 1.74 \\
\hline Cup & Outer & 981D371 HOI & 79246 & 3 & 46 & 41 & 1.12 \\
\hline Cup & $\begin{array}{l}\text { Long } \\
\text { Outer }\end{array}$ & $981 \mathrm{D} 371 \mathrm{HO} 2 \mathrm{~A}$ & 79246 & 3 & 14 & 10 & 1.40 \\
\hline Cup & Pyro & $981 D 391$ HOZB & 7752 & 5 & 78 & 48 & 1.62 \\
\hline Cup & $\begin{array}{l}\text { Long } \\
\text { Pyro }\end{array}$ & $981 D 391$ HO38 & 77452 & 5 & 10 & 8 & 1.25 \\
\hline Washer & Topered & $9810368 \mathrm{HOI}$ & 79248 & 5 & 94 & 72 & 1.31 \\
\hline
\end{tabular}


TABLE 8 (CRD)

PEWEE-I ELEMENT PERMEABILITY (U)

\begin{tabular}{|c|c|c|c|c|c|c|c|c|c|c|}
\hline \multirow[b]{2}{*}{ Supplier } & \multirow{2}{*}{$\begin{array}{l}\text { Fuel } \\
\text { Element } \\
\text { Loading }\end{array}$} & \multicolumn{8}{|c|}{$\begin{array}{c}\text { Ranges of Leak Rate (cc/min.) } \\
\text { (As-Leached) }\end{array}$} & \multirow{2}{*}{$\begin{array}{l}\text { Total } \\
\text { Fuel } \\
\text { Elements } \\
\text { Evaluateo }\end{array}$} \\
\hline & & $0-99$ & $\%$ & $100-169$ & $\%$ & $170-199$ & $\%$ & $\begin{array}{c}200-\& \\
\text { Over }\end{array}$ & $\%$ & \\
\hline WNCO & 525 & 112 & 36 & 131 & 42 & 28 & 9 & 39 & 13 & 310 \\
\hline$Y-12$ & 477 & 34 & 44 & 43 & 56 & 0 & & 0 & & 77 \\
\hline$Y-12$ & 269 & 59 & 81 & 7 & 10 & 1 & 1 & 6 & 8 & 73 \\
\hline
\end{tabular}


TABLE 9 (CRD)

PEWEE-I EXTRUSION RUN (U)

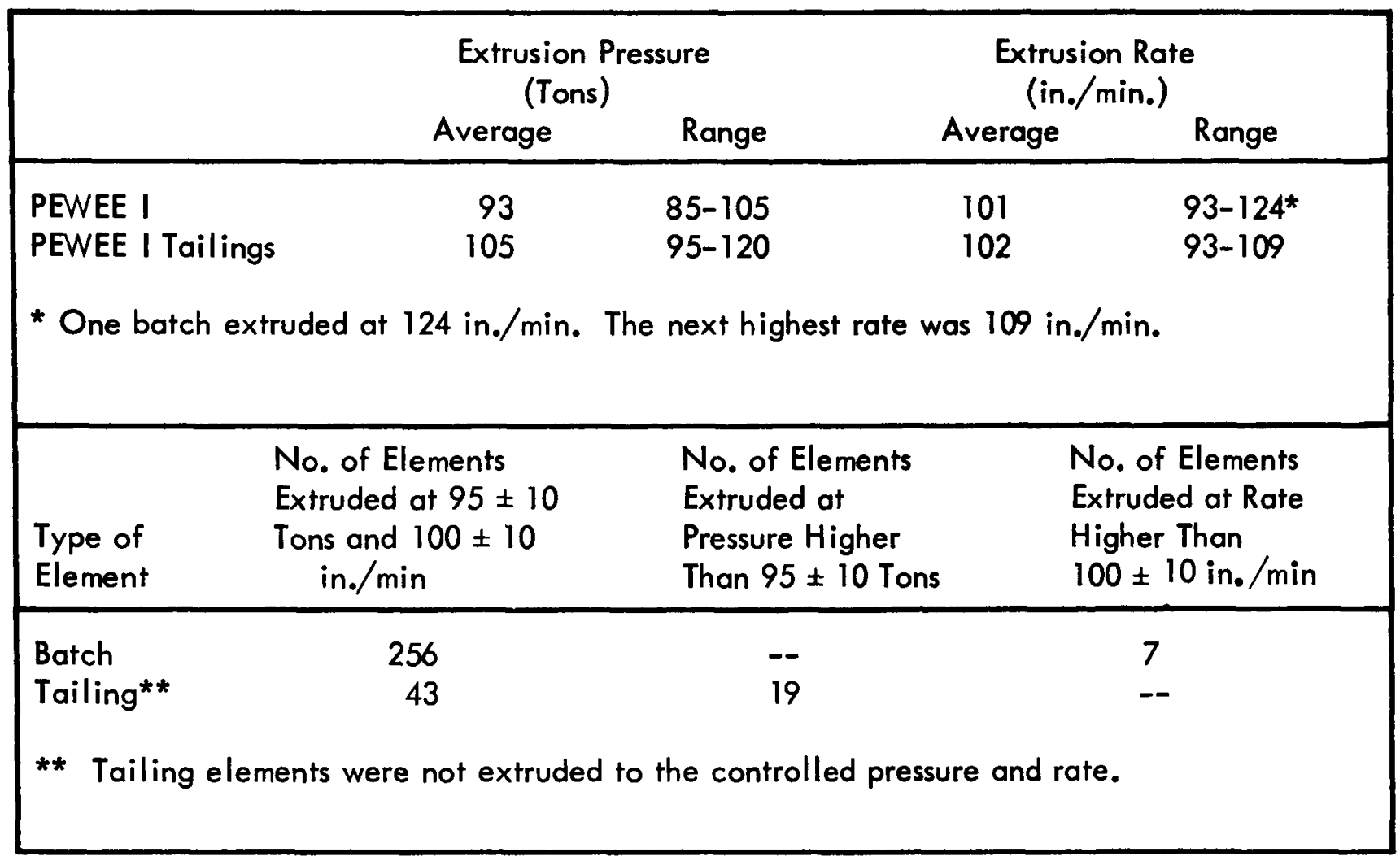


TABLE 10 (CRD)

PEWEE I "X"-COAT PRODUCTION RUNS (U)

\begin{tabular}{|c|c|c|c|c|c|c|}
\hline $\begin{array}{c}\text { "X" Run } \\
\text { No. }\end{array}$ & $\begin{array}{c}\text { NbC } \\
\text { Run No. }\end{array}$ & F/E Type & $\begin{array}{c}\text { No. of } \\
\text { F/E }\end{array}$ & $\begin{array}{c}\text { Avg. Wt. } \\
\text { Dep.* }\end{array}$ & $\begin{array}{c}\text { Avg. Wt. } \\
\text { B/D** }\end{array}$ & $\begin{array}{c}\text { Avg. Wt. } \\
\text { Ret.*** }\end{array}$ \\
\hline AA-174 & M-136 & G05K (S) & 17 & 4.97 & 0.88 & 4.09 \\
& G-396 & G05K (S) & 18 & 5.07 & 0.99 & 4.08 \\
AA-175 & M-137 & G07K (A) & 17 & 4.92 & 1.11 & 3.81 \\
& L-313 & G06K (I) & 16 & 5.01 & 0.45 & 4.56 \\
AA-177 & L-314 & G05K (S) & 18 & 5.05 & 1.20 & 3.85 \\
& G-397 & G07K (A) & 16 & 4.93 & 0.42 & 4.51 \\
AA-178 & C-398 & G06K (I) & 17 & 4.96 & 0.55 & 4.41 \\
& F-387 & G05K (S) & 18 & 5.15 & 0.80 & 4.35 \\
& M-138 & G04K (A) & 17 & 5.04 & 0.76 & 4.28 \\
& M-139 & G04K (A) & 17 & 5.35 & 1.15 & 4.20 \\
\hline
\end{tabular}

$S=$ Standard; $I=$ Impregnated; $A=$ Additive

* Average Weight Deposition = Average Weight of Mo deposited in the coating run.

** Average Weight $B / D=$ Average Weight of Mo blown from the elements of a coating run in the room temperature blowdown cycle.

$* * *$

Average Weight Retention = Average Weight of Mo remaining in the elements of a coating run as shipped. 